\title{
Genetic structure of Zephyranthes fosteri, specie with ornamental and medicinal potential in Mexico
}

\author{
Estructura genética de Zephyranthes fosteri, especie con potencial ornamental y medicinal en México
}

\author{
Martha Isabel Torres-Morán', Ana Paulina Velasco-Ramírez*, Norma Almaraz-Abarca², Julio Yesua Anaya- \\ Covarrubias ${ }^{1}$, Alejandro Velasco-Ramírez' \\ Instituto de Manejo y Aprovechamiento de los Recursos Fitogenéticos. Centro Universitario de Ciencias Biológicas y \\ Agropecuarias. Universidad de Guadalajara. Camino Ramón Padilla Sánchez No. 2100 Nextipac, Zapopan, Jalisco. 45110. \\ México \\ 2 Centro Interdisciplinario de Investigacion para el Desarrollo Integral Regional (CIIDIR-IPNUnidad Durango), Departamento \\ de Biotecnologia, Sigma s/n, Fraccionamiento 20 de Noviembre II, 34220, Durango, Durango, Mexico.
}

\section{ABSTRACT}

Zephyranthes fosteri is a wild species distributed in Mexico, it is popular for its ornamental quality. Anthropogenic activities perturbed its natural habitats and threaten its survival. At present time, there is not enough information about the genetic relationships and structure among $Z$. fosteri distributed in Mexico. The objective of this investigation was to elucidate the genetic relationships and structure among accessions of $Z$. fosteri collected in western and southeastern Mexico. ISSR markers were used to establish the genetic variability and genetic structure among 60 accessions randomly collected in western Mexico and one population found in southeastern Mexico. Jaccard's coefficient and AMOVA analysis determined the similarity and variability among and within accessions, and Bayesian model was used to assess the genetic structure. A mean heterozygosity of 0.49 was found indicated a moderate variability. The AMOVA analysis showed that $75 \%$ of this variability was within accessions, and $25 \%$ among accessions. A $56.75 \%$ polymorphism was detected with ISSR markers, and genetic structure analysis identified four genetic groups.

Keywords: ornamental plants; ISSR; geophytes; Amaryllidaceae

\section{RESUMEN}

Zephyranthes fosteri es una especie silvestre que se encuentra en diferentes partes del territorio Mexicano y que es popular por su calidad ornamental. Su hábitat ha sido constantemente perturbado por actividades antropogénicas amenazando su supervivencia. Existe poca información sobre las relaciones genéticas y la estructura entre $Z$. fosteri en México. El objetivo de esta investigación fue dilucidar las relaciones y la estructura genética entre las accesiones de $Z$. fosteri recolectadas en el occidente y sureste de México. Los marcadores ISSR se usaron para establecer la variabilidad y estructura genética entre 60 accesiones tomadas al azar en el occidente y una población encontrada en el sureste de México. El coeficiente de Jaccard y el Análisis Molecular de Varianza (AMOVA) determinaron la similitud y la variabilidad entre y dentro de las accesiones. Se utilizó el modelo bayesiano para

*Autor para correspondencia: Ana P.Velasco-Ramírez

Correo electrónico: pauvela73@hotmail.com

Recibido: 08 de mayo de 2018

Aceptado: 10 de octubre de 2018 determinar estructura genética. Una heterocigosidad de 0.49 indicó una variabilidad moderada y los resultados del análisis AMOVA mostraron que $75 \%$ y $25 \%$ de esta variabilidad se encontraban inter e intrapoblacional respectivamente. Se detectó polimorfismo de $56.75 \%$ y el análisis de la estructura genética identificó cuatro grupos genéticos, asignando cada muestra a un grupo.

Palabras claves: plantas ornamentals; ISSR; bulbosas; Amaryllidaceae

\section{INTRODUCTION}

The genus Zephyranthes (Amaryllidaceae) comprises approximately 70 species with neotropical distribution (Hutchinson 2003; Judd et al., 1999). Zephyranthes species has potential as geophytes within landscape design since it benefits from the natural vegetation of the region optimizes the plating design both aesthetically and functionally (Seyidoglu et al., 2009).

Zephyrantes fosteri Traub is a wild perennial herbaceous plant with beautiful flowers and reproductive bulbs. It is commonly known as mayito because its flowers appear in May (Padilla-Sánchez et al., 2016). Its elegant appearance gives this species the potential to be appreciated as a decorative landscape element or as a potted plant (Seyidoglu et al., 2009). It is mainly found in forest areas and has been reported in Mexico's western and southern regions as well as in the State of Jalisco, Mexico (Tapia-Campos et al., 2012). Nowadays this species can be found as part of some people's collection, as a potted ornamental plant. Populations of the plants in the wild, are being fragmented by anthropogenic activities such as new road construction and housing developments and consequently it genetic variability could be threatened and make its conservation more difficult (Barrett and Kohn, 1991; Withlock et al., 2011).

Multi-locus markers such as Inter Simple Sequence Repeats (ISSR) have been successfully used to assess the genetic variability of several plants (González et al., 2005; Takrouni and Boussaid, 2010; Vargas-Ponce et al., 2011). Each ISSR fragment represents a locus between two microsatellites, and its amplified profile provides a fingerprint for independent 
individuals (González and Aguirre, 2007; Basha et al., 2009; Wu et al., 2014). In addition, Bayesian population analysis can assess genetic coincidences and similarities among populations and can assist in documenting the population genetic status. This method relates the allele frequencies, amongst a set of samples that define a population, to the frequencies found in individuals of differentiated populations (PorrasHurtado et al., 2013).

The lack of reports describing the genetic variability of $Z$. fosteri, its industrial potential medicinal use, since this species contains inhibitory alkaloids to treat mild to moderate Alzheimer's symptoms disease (Bastida et al., 2006), and endanger status makes the assessment of its genetic variability a priority in ornamental and plant resources. This new information, will contribute to the development of rational conservation, exploitation as well as breeding and domesticating strategies for the species. The objective of this investigation was to elucidate the genetic structure and the genetic variability among accessions of $Z$. fosteri collected in western Mexico and compare with one population found in Southeastern Mexico.

\section{MATERIALS AND METHODS}

\section{Plant material and sampling sites}

Bulbs and plants were collected in four mexican localities, three located in the western states of Jalisco, Michoacan (Highland and Valleys zones in Michoacan) and Nayarit, as well as a locality in the southeast of Mexico (Yucatan) where it had not been reported in this locality (Table 1, Figure 1). Plants were identified using Mc Vaugh (1989) taxonomic key, and a herbarium voucher of each group deposited at the Herbarium of the Instituto de Botánica Universidad de Guadalajara (IBUG). Bulbs of plants were conserved as in vivo accessions in a nursery at Centro Universitario de Ciencias Biológicas y Agropecuarias (CUCBA), Universidad de Guadalajara located at $20^{\circ} 45^{\prime} \mathrm{N}$ and $103^{\circ} 31^{\prime} \mathrm{W}$ with altitude of 1650 above the sea level.

Bulbs were individually planted (Figure 2) in pots containing a humus soil-pumice substrate (1:1) and placed in the CUCBA nursery. A nutritive formula containing $\mathrm{N}, \mathrm{P}$, and K (20-20-20) was added to each pot every two weeks until leaves were fully developed and ready for being collected for DNA extraction.

Table 1. Origin and classification of accessions of Zephyranthes fosteri. Tabla 1. Origen y clasificación de accesiones de Zephyranthes fosteri.

\begin{tabular}{|c|c|c|c|}
\hline Location & Code & $\begin{array}{l}\text { Geographical } \\
\text { position }\end{array}$ & $\begin{array}{l}\text { Distinguishable } \\
\text { trait (Flowers } \\
\text { color) }\end{array}$ \\
\hline Michoacán & $\mathrm{M} 1$ to $\mathrm{M} 8$ & West & Violet \\
\hline Nayarit & $\mathrm{N} 1$ to $\mathrm{N} 22$ & West & Violet \\
\hline $\begin{array}{l}\text { Jalisco (Highland } \\
\text { zone) }\end{array}$ & $\mathrm{ZA} 01$ to $\mathrm{ZA} 27$ & West & Violet \\
\hline $\begin{array}{l}\text { Jalisco } \\
\text { zone) }\end{array}$ & Za1 to Za 6 & West & White \\
\hline Yucatán (Mérida) & MY1 to MY7 & South & White \\
\hline
\end{tabular}

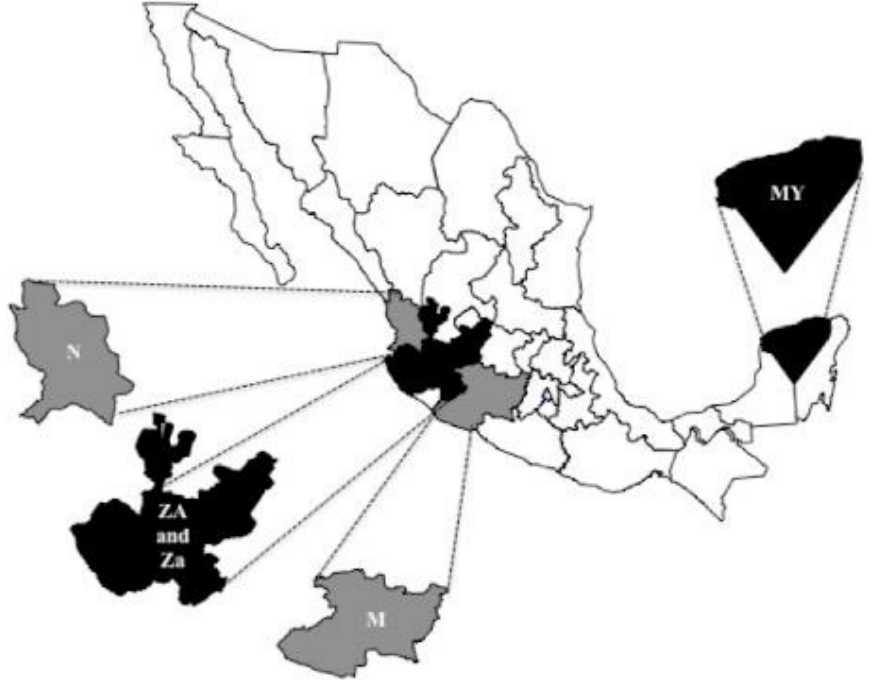

Figure 1. Geographic location of the wild populations of collected Zephyranthes fosteri. M: Michoacan; N: Nayarit (Western zone); ZA: Jalisco (Highland zone); Za: Jalisco (Valleys zone); MY:Yucatan Merida (Southeastern zone).

Figura 1. Ubicación geográfica de las poblaciones silvestres de Zephyranthes fosteri recolectadas. M: Michoacán; N: Nayarit (zona occidental); ZA: Jalisco (zona de las tierras altas); Za: Jalisco (zona de los Valles); MY: Yucatán, Mérida (zona sureste).

\section{DNA extraction}

Foliar DNA was isolated according to the CTAB (Cetyl Trimethyl Ammonium Bromide) procedure by Keb-Llanes et al. (2002), and then analyzed for purity and concentration by standard electrophoretic and spectrometric methods (Sambrook and Russell, 2001).

\section{Amplification conditions}

Five ISSR primers from 15 sequences selected from the University of British Columbia (2015) and University State the Ohio (2000) $(843,899,16,901, \mathrm{BECKY})$ databases were chosen for amplification (Table 2). Amplification was carried out in $20 \mu \mathrm{L}$ of $1 \mathrm{X}$ PCR buffer containing $2.5 \mathrm{mM} \mathrm{MgCl} \mathrm{2}^{\prime} 0.8$ $\mu \mathrm{M}$ of primer, $0.25 \mathrm{mM}$ dNTPs, $4 \mathrm{ng}$ of DNA, and $0.05 \mathrm{U}$ of Taq DNA polymerase (Promega ${ }^{\circ}$ ). PCR cycling included 3 min at $95^{\circ} \mathrm{C}$ followed by 40 cycles of $45 \mathrm{~s}$ each at $95^{\circ} \mathrm{C}$ (DNA denaturalization), $45 \mathrm{~s}$ at $52{ }^{\circ} \mathrm{C}$ (annealing), $1 \mathrm{~min} 30 \mathrm{~s}$ at 72

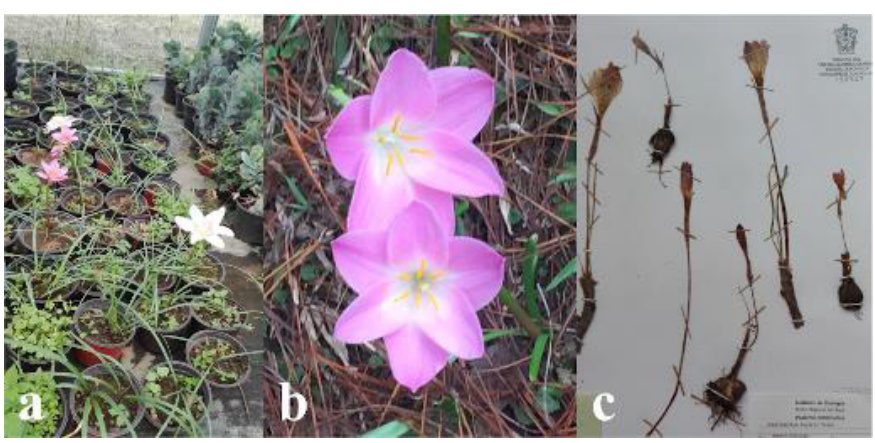

Figure 2. Zephyranthes fosteri. (a) Individuals in plant nursery. (b) Flowers. (c) Herborized voucher specimens.

Figura 2. Zephyranthes fosteri. (a) Individuos establecidos en vivero. (b) Flores. (c) Especimenes ejemplares de herbario. 
Table 2. ISSR primers sequences and polymorphism based on resulting banding patterns of Zephyranthes fosteri.

Tabla 2. Secuencia de cebadores ISSR y polimorfismo basados en los patrones de bandas para Zephyranthes fosteri.

\begin{tabular}{llcc}
\hline Primer & Sequence $\left(\mathbf{5}^{\prime} \mathbf{- 3}^{\prime}\right.$ ) & Amplicons & $\begin{array}{c}\text { Polymorphism } \\
\text { (\%) }\end{array}$ \\
\hline 843 & CTC TCT CTC TCT CTC TRA & 124 & 53.22 \\
899 & CAT GGT GGT GGT CAT TGT & 134 & 55.22 \\
\hline 16 & YRG ACA GAC AGA CA & 111 & 43.24 \\
901 & GTC TGT GTG TGT YR & 122 & 59.01 \\
BECKY & CAC ACA CAC ACA CAY C & 26 & 73.07 \\
& Global & 517 & 56.75 \\
\hline
\end{tabular}

${ }^{\circ} \mathrm{C}$ (extension), and a final extension at $72^{\circ} \mathrm{C}$ for $10 \mathrm{~min}$. The amplified fragments were separated by electrophoresis on 6 $\%$ polyacrylamide gels and stained with silver salts according to Sanguinetti et al. (1994) and, Sambrook and Russell (2001).

\section{Data analysis}

Binary matrixes of presence/absence ( $1 / 0$ respectively) were codified from the amplified fragment data and Jaccard's similarity coefficient was determined. Analysis of molecular variance (AMOVA) and the variance components, among and within accessions, and their statistical significance was calculated using GenAIEX v. 6.5 (Peakall and Smouse, 2012) and Infogen (Balzarini and Di Rienzo, 2016), respectively. A cluster analysis, using the Unweighted Paired Group Method with Arithmetic Averages (UPGMA). Bootstrap as support for stastical sampling was used, with $10^{10}$ iterations. Analyses were performed using FreeTree, TreeView and NTSYS-pc 2.21 softwares (Hampl et al., 2001; Reif et al., 2004; Rohlf, 2009).

Genetic variability and informativeness of the ISSR markers were tested through the Polymorphic Information Content $(P I C)$, heterozygosity per locus $(\mathrm{He})$, average heterozygosity (Hav), the multiplex ratio (MR) and marker Index (MI) (Roldán-Ruiz et al., 2000). The genetic structure was estimated using the STRUCTURE software (v. 2) (Pritchard et al., 2000) four simulations were performance using $K=2$ to $K=5$ by an admixture model with $10^{5}$ iterations, and $10^{5}$ burn-in periods ( $K=$ number of simulated groups). The differentiation coefficient (Fst) based on allelic frequencies, as well as the average heterozygosity for each population were calculated (IPGRI, 2003). Finally, the Evanno method was estimated in order to determine the adequate number of simulated groups $(K)$ using Structure Harvester online software (Evanno et al., 2005; Earl and VonHoldt, 2012).

\section{RESULTS}

\section{Taxonomic}

The taxonomic analysis confirmed that all the individuals collected belonged to the species Zephyranthes fosteri (Figure 2).

\section{Molecular marker informativeness}

A total of 517 fragments were amplified. The number of amplicons per primer, percentage of polymorphism and amplicon sizes varied from 26 to 134,43 to 73 , and 150 to $2500 \mathrm{pb}$, respectively (Table 2). Table 3 contains both, the ISSR markers effectiveness values and the average heterozygosity (Hav).

Table 3. Marker effectiveness. Parameters for ISSR markers used in Zephyranthes fosteri wild populations.

Tabla 3. Efectividad del marcador. Parámetros del marcador ISSR utilizados en poblaciones silvestres de Zephyranthes fosteri.

\begin{tabular}{ll}
\hline Parameters for marker efficiency & ISSR \\
\hline Number of individuals & 60 \\
Total number of bands $(L)$ & 517 \\
Polymorphic bands $(p)$ & 279 \\
Total number primer combinations $(T)$ & 5 \\
Multiplex ratio $(M R)(L / T)$ & 103.4 \\
Polymorphism percentage (\%p) & 56.75 \\
Polymorphic information content $(P I C)$ & 0.59 \\
Average heterozygosity (Hav) & 0.49 \\
Marker index $(M I)$ Hav $\times$ MR & 50.66 \\
\hline
\end{tabular}

\section{Genetic variability and structure}

The dendrogram in Figure 3 shows that individuals from the various regions are grouped into one of four groups (S1, S2, S3, and S4), according to the UPGMA cluster analysis. Group S1 included individuals collected in Michoacán (M) and Nayarit (N), group S2 group consisted of individuals from

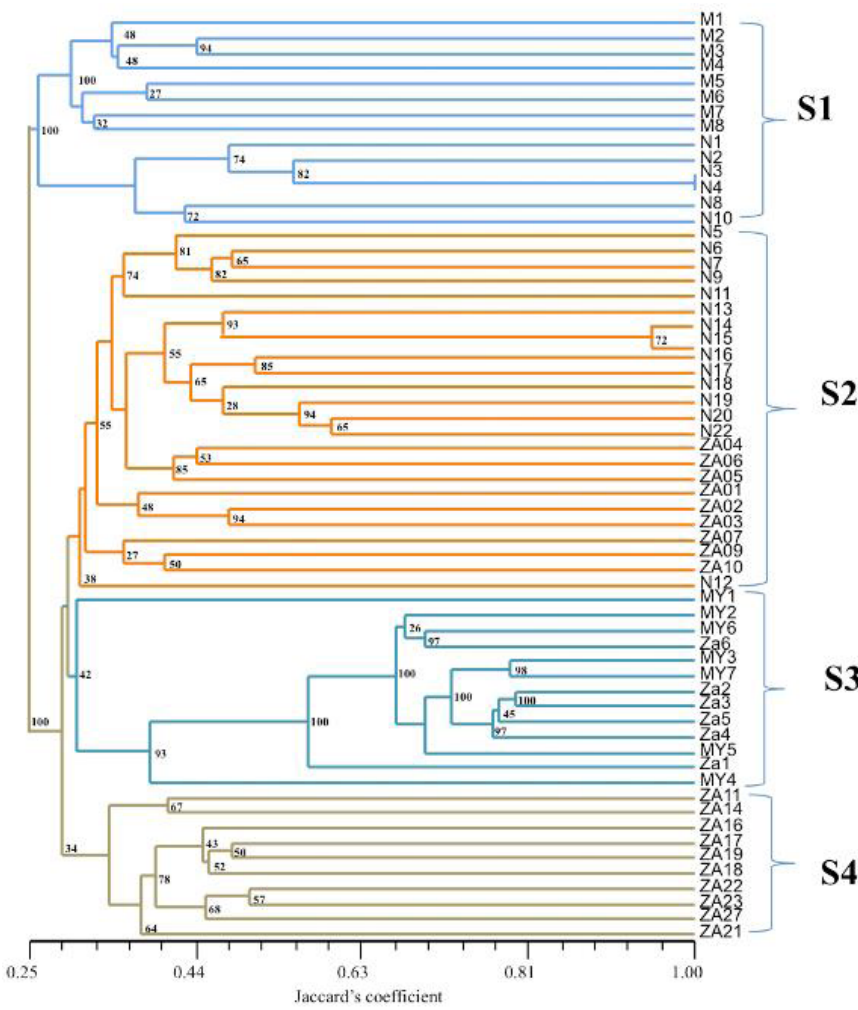

Figure 3. Clustering analyses (UPGMA) and boostrap, based on ISSR markers, showing the genetic relationships among Zephyranthes fosteri individuals.

Figura 3. Análisis de agrupamiento (UPGMA) y remuestreo, basado en marcadores ISSR, que muestras las relaciones genéticas entre los individuos de Zephyranthes fosteri. 
Nayarit with some from Jalisco (Za) (Valleys zone), group the S3 included individuals collected in Yucatan (Merida) and Jalisco (Valleys zone) and group S4 individuals from Jalisco (ZA) (Highland zone).

Results of similarity analyses show the highest similarity $(0.80)$ between the Yucatan and Jalisco Valleys populations, and the lowest (0.25) between the Michoacan and Nayarit. Individuals in the S3 group (MY and $\mathrm{Za}$ ) were genetically similar. Figure 4 shows the results of the genetic structure with simulations of $K=2$ to $K=5$ indicated with a different color and the assignment of individuals to a particular group was indicated too. The outcome of both, the STRUCTURE analysis (probabilistic value $\operatorname{LnP}(D)=-2213$ ) and the Evanno test (highest Delta $K$ value $=5.76$ ) indicated that $K=4$ was the optimal number of groups. The AMOVA analysis demonstrated significant differences in the variability among and within accessions ( $25 \%$ and $75 \%$ respectively) (Table 5 ).

Bayesian probability analysis differentiated in every simulation, the MY plus Za from all others groups and the results were consistent with those obtained in the cluster analysis (Figure 3).

Table 4 contains the result of the genetic differentiation analysis (Fst). The highest genetic differentiation (Fst) value was found for the S3 group (0.5738), whereas, the S2 group had the lowest differentiation value (0.2319). Genetic differentiation $(F s t)$ and Heterozigosity $(\mathrm{He})$ values for the four groups are also included in Table 4. Major heterozygosity was found in the S1 group (0.3309).

Table 4. Genetic differentiation ( $F s t$ ) and expected heterozigosity $(\mathrm{He})$ for $K=4$ simulation for individuals of Zephyranthes fosteri.

Tabla 4. Diferenciación genética $(F s t)$ y Heterocigocidad esperada $(\mathrm{He})$ para simulación de $K=4$ para individuos de Zephyranthes fosteri.

\begin{tabular}{|c|c|c|c|c|}
\hline $\begin{array}{l}\text { Cluster } \\
\text { identification }\end{array}$ & $\begin{array}{l}\text { Similarity } \\
\text { within } \\
\text { groups }\end{array}$ & $\begin{array}{l}\text { Assigned } \\
\text { group in } \\
\text { simulation }\end{array}$ & $\begin{array}{l}\text { Differentiation } \\
\text { coefficient (Fst) }\end{array}$ & $\begin{array}{l}\text { Expected } \\
\text { heterozygosity }\end{array}$ \\
\hline S1 & $0.28-0.55$ & Yellow & 0.4228 & 0.3309 \\
\hline S2 & $0.28-0.96$ & $\begin{array}{l}\text { Yellow and } \\
\text { blue }\end{array}$ & 0.2319 & 0.3111 \\
\hline S3 & $0.32-0.81$ & Green & 0.5738 & 0.1536 \\
\hline S4 & $0.35-0.51$ & $\begin{array}{l}\text { Yellow and } \\
\text { red }\end{array}$ & 0.2905 & 0.2898 \\
\hline
\end{tabular}

Table 5. Analysis of molecular variance (AMOVA) for ISSR markers in 60 individuals of Zephyranthes fosteri.

Tabla 5. Análisis de la varianza molecular (AMOVA) para el marcador ISSR en 60 individuos de Zephyranthes fosteri.

\begin{tabular}{lccccccc}
\hline $\begin{array}{l}\text { Source of } \\
\text { variation }\end{array}$ & df & SS & MS & Est. Var. & $\begin{array}{c}\text { Vof of. } \\
\text { Var. }\end{array}$ & PhiPT & P \\
\hline Among Pops & 4 & 1753.846 & 438.461 & 30.532 & $25 \%$ & 0.249 & 0.001 \\
Within Pops & 56 & 5143.466 & 91.848 & 91.848 & $75 \%$ & & \\
Total & 60 & 6897.311 & & 122.380 & $100 \%$ & & \\
\hline
\end{tabular}

df: degree of freedom, SS: sum of square, MS: square medium, Est. Var: standard variation, $\%$ of Var: percentage of variation, PhiPT: estimator of the average genetic differentiation, P: probability
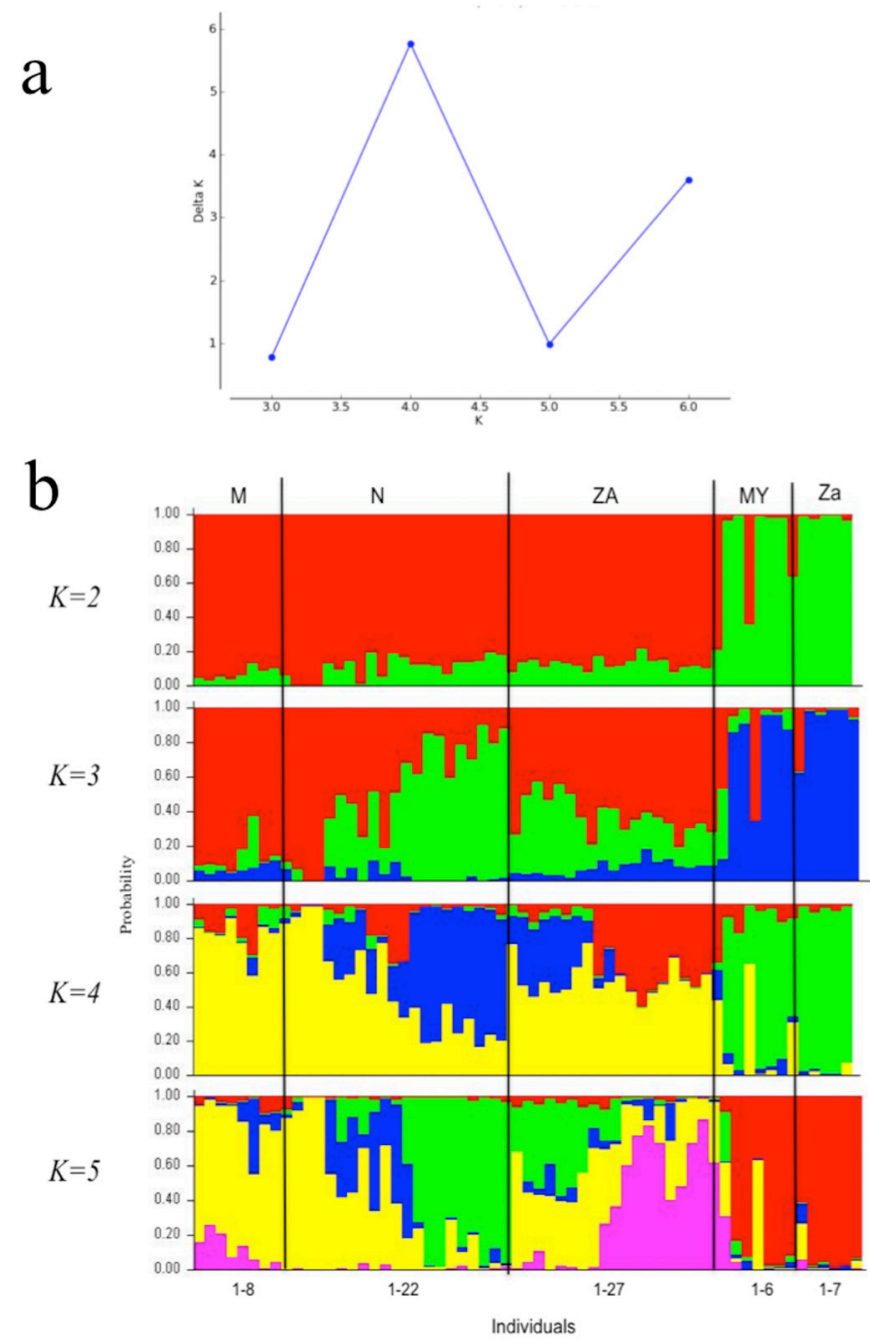

Figure 4. (a) Magnitude of $\Delta K$ as a function of $K$ from Evanno method. The peak value of $\Delta K$ was at $K=4$, suggesting four groups for Zephyrnthes fosteri wild populations. (b) Simulations $K=2$ to $K=5$, to determine genetic structure of Zephyranthes fosteri wild populations based on ISSR markers. $M$, $\mathrm{N}$ and ZA from Western zone, Za from Valley zone and MY from Southeaster zone.

Figura 4. (a) Magnitud de $\Delta K$ como una función de $K$ del método de Evanno. El valor máximo de $\Delta K$ fue $K=4$, sugiriendo cuatro grupos para las poblaciones silvestres de Zephyrnthes fosteri. (b) Simulaciones $K=2$ a $K=5$, para determinar la estructura genética de poblaciones silvestres de Zephyranthes fosteri basadas en marcadores ISSR. M, N y ZA de la zona occidental, Za de la zona del Valle y MY de la zona del sureste.

\section{DISCUSSION}

The outcome of this study is based on 517 loci from 60 individuals and meets the requirements for a reliable sample (Nei, 1978; Brown et al., 1983). The total loci detected with ISSR markers in this study are reliable for genetic analysis ( $\mathrm{Ng}$ and Tan, 2015). As Ferraro et al. (2013), reported ISSR markers have been proven to be an efficient marker, and result to be appropriate to detect high levels of polymorphism among $Z$. fosteri.

The results obtained supports that ISSR markers are useful for detecting genetic variability and genetic relationships among wild plant species (Valdés De La Cruz et al., 2010; Onaum et al., 2015; Jae-Han et al., 2012). The level of poly- 
morphism found in this study (56.75\%) (Table 3 ) is similar to that of lingonberry (Vaccinium vitis-idaea L.) (Debnath, 2006) and orange (Citrus indica) (Kumar et al., 2010) detected with the same marker.

A PIC value of 0.59 (Table 3 ), calculated with $>20$ individuals and $>50$ detected loci, indicates that the ISSR primers identified a modest number of informative loci (Nei, 1978; Bussell et al., 2005). PIC values obtained with other species such as sugar cane (0.45) (Devarumath et al., 2012) and Opuntia (0.27) support this fact (Valadez-Moctezuma, 2015).

The Hav value obtained was similar to those of some wild species of Dioscorea (0.45) (Velasco-Ramírez et al., 2014) but higher than for Tribulus terrestris (0.31) (Sarwat et al., 2008). A Hav of 0.4 suggests the presence of enough variability for not considering this species under threat of extinction. Intra and inter population variability were also found in the Z. fosteri.

The group patterns obtained from the cluster analysis indicated the presence of two genotypes in Nayarit, two genotypes in Jalisco and another one to the Michoacán cluster, that could be sources of worthy alleles for the development of commercial varieties with violet flowers. Genetically, the Yucatan (MY) and Jalisco Valley populations (Za) were the closest populations (Figure 3) this was unexpected given the significant geographical distance and the orographic barriers between locations, that difficults the genetic flux between the them. The similarity between the populations would have been more clear if they were distributed from south to north as is the case for several other crops and wild ornamentals (Heiser and Nelson, 1974; Eid et al., 2011; Piperno, 2011). On the other hand, individuals from these regions shared white flowers and had a high probability of belonging to the same genetic population. Conversely, the cluster comprised of Michoacan (M), Nayarit (N) and Jalisco (ZA) populations was consistent with its geographical origin (western region). The use of the genus Zephyranthes in traditional medicine, in Mexico and Latin American, and its recognition as a medicinal plant among local people could explain its distribution and establishment in Yucatan and Jalisco (Martínez and Cúneo, 2009; Ávila, 2012).

The genetic variability results (Table 4) indicates that group S2 had the largest range of similarity values while the S4 cluster had the shortest, possibly due to different adaptation processes to environmental conditions including soil and climate or a concordance among morphological characters such as flower color. Assessment of the genetic variability in wild species offers the possibility of identifying and selecting valuable alleles for the development of commercial varieties. Also, it offers the potential to modify important economic attributes for ornamental plants like propagation easiness, color, and shapes of leaves and flowers, as well as plant architecture (Dandekar, 2003).

Genetic structure results fits with the AMOVA analyses (Figure 4). Even with a few individuals in the MY and Za groups, the simulations consistently assigned both accessions to a unique simulated group ( $K$ ). This outcome is reliable based on the principles established by Porras-Hurtado et al. (2013) for the Bayesian method and for assigning mixed individuals to clusters, based on the number of loci detected with ISSR (Ng and Tan, 2015; Nelson and Anderson, 2013).

\section{CONCLUSIONS}

ISSR were useful markers in assessing the genetic variability of wild populations of $Z$. fosteri and can be used to discriminate between genotypes. As the main natural propagation of this species is asexual, determination of genetic variability is relevant. The genetic variability found in this study, the climate change, and the accelerated growth of buildings and roads are good reasons to establish conservation and breeding programs for wild ornamental plants. This study is a starting point for further research targeting both, the selection of alleles associated with morphological features for developing economically important ornamental varieties and initiating conservation efforts.

\section{REFERENCES}

Ávila, A. 2012. Yerba del coyote, veneno del perro: la evidencia léxica para identificar plantas en el códice de la Cruz Badiano. Acta Bot Mex 100: 489-526.

Balzarini, M.G., Di Rienzo, J.A. 2016. InfoGen. FCA, Universidad Nacional de Córdoba, Argentina. http://www.info-gen.com. ar. Accessed: 17 February 2016

Barrett, S.C.H., Khon, J.R. 1991. Genetic and evolutionary consequences of small population size in plants: implications for conservation. In: D. A. Falk and K. A. Holsinger (eds). Genetics and conservation of rare plants. Oxford University Press, Oxford, United Kingdom. 30 p.

Basha, S.D., Francis, G.H.P.S., Makkar, K., Becker K., Sujatha, M. 2009. A comparative study of biochemical traits and molecular markers for assessment of genetic relationships between Jatropha curcas L. germplasm from different countries. Plant Sci 176: 812-823.

Bastida, J., Lavilla, R., Viladomat, F. 2006. Chemical and biological aspects of Narcissus alkaloids. The Alkaloids: Chemistry and Biology 63: 87-179.

Brown, A.H.D., Weir, B.S. 1983. Measuring genetic variability in plant populations. In: S. D. Tanksley and T. J. Orton (eds.). Isozymes in Plant Genetics and Breeding, part A. Elsevier Science Publishers, Amsterdam, pp 219-239.

Bussell, J.D., Waycott, M., Chappill, J.A. 2005. Arbitrarily amplified DNA markers as characters for phylogenetics. Perspectives in Plant Ecology. Evolution and Systematics 7: 3-26.

Dandekar, A.M. 2003. Technologies for manipulating quality and productivity traits in horticultural crops. Acta Hortic 625: 293-305.

Debnath, S.C. 2006. Inter Simple Sequence Repeat (ISSR) to assess genetic diversity within a collection of wild lingonberry (Vaccinium vitis-idaea L.) clones. Can J of Plant Sci 148: 313-322.

Devarumath, R., Kalwade, S., Kawar, P., Sushir, K. 2012. Assessment of genetic diversity in sugarcane germplasm using ISSR and SSR markers. Sugar Tech 14: 334-344.

Earl, D.A., VonHoldt, B.M. 2012. STRUCTURE HARVESTER: a website and program for visualizing structure output and implementing the Evanno method. Conservation Genet Resources 4: 359-361.

Eid, S., Saar, D.E., Druffel, K.L., Pappu, H.R. 2011. Plant pararetroviral sequences in wild Dahlia species in their natural habitats in Mexican mountain ranges. Plant Pathol 60(2): 378-382. 
Evanno, G.S., Regnaut., Goudet, J. 2005. Detecting the number of clusters of individuals using the software STRUCTURE: a simulation study. Mol Ecol 14(8): 2611-2620.

González, A., Wong, A., Delgado-Salinas, A., Papa, R., Gepts, P. 2005. Assessment of Inter Simple Sequence Repeat Markers to differentiate sympatric wild and domesticated populations of common bean. Crop Science 45: 606-615.

González, A., Souza, V., Aguirre, X. 2007. Inter Simple Sequence Repeats (ISSRs) (19). Ecología Molecular, México. Secretaría de Medio Ambiente y Recursos Naturales, Instituto Nacional de Ecología, Comisión Nacional para el Conocimiento y Uso de la Biodiversidad (CONABIO). Instituto de Ecología, UNAM, México, pp 567-571.

Hampl, V., Pavlícek, A., Flegr, J. 2001. Construction and Bootstrap analysis of DNA fingerprinting-based phylogenetic tress with the freeware program FreeTree: Application to Trichomonad parasites. Application to Trichomonad parasites. Int J Syst Evol Microbio 51: 731-5.

Heiser, C.H., Nelson, D.C. 1974. On the origin of the cultivated Chenopods (Chenopodium). Genetics 78: 503-505.

Hutchinson, J. 2003. The families of flowering plants. Clarendon, Oxford.

IPGRI. 2003. Genetic diversity analysis with molecular marker data: learning module. The International Plant Genetic Resources Institute and Cornell University, USA, pp 71.

Jae-Han, S., Kyong-Cheul, P., Sung-II, L., Jong-Hwa, K., Nam-Soo, K. 2012. Species relationships among Allium species by ISSR analysis. Hortic Environ Biotechnol 53(3): 256-262.

Judd, W.S., Campbell, C.S., Kellogg, E.A., Stevens, P.F. 1999. Plant systematics: a phylogenetic approach. Sinauer, Massachusetts.

Keb-Llanes, M., González, B., Chi-Manzanero, B., Infante, D.A. 2002. Rapid and simple method for small-scale DNA extraction in Agavaceae and other tropical plants. Plant Mol Biol Report 20: 299a-299e.

Kumar, S., Nair, N.K., Narayanan, S.J. 2010. ISSR polymorphism in Indian wild orange (Citrus indica Tanaka, (Rutaceae)) and related wild species in northeast India. Sci Hortic 123: 350359.

Martínez, G., Cúneo, P. 2009. Las denominaciones vernáculas y el conocimiento toba del entorno vegetal. Revista de dialectología y tradiciones populares 64(2): 149-168.

Mc Vaugh, R. 1989. Bromeliaceae to Discoreaceae. Flora NovoGaliciana A descriptive account of the vascular plants of western de Mexico (15). The University of Michigan Herbarium, Ann Arbor, Michigan. 398.

Nelson, M.F., Anderson, N.O. 2013. How many marker loci are necessary? Analysis of dominant marker data sets using two popular population genetic algorithms 3(10): 3455-3470.

Nei, M. 1978. Estimation of average heterozygosity and genetic distance from small number of individuals. Genetics 89: 583590.

Ng, W.L., Tan, S.G. 2015. Inter-Simple Sequence Repeat (ISSR) markers: are we doing it right? ASM Science Journal 9(1): 30-39.

Padilla-Sánchez, A., Andrade-Rodriguez, M., Alia-Tejacal, I., Villegas-Torres, O.G., Guillen-Sánchez, D. 2016. Propagación vegetativa y sexual de mayito (Zephyranthes fosteri Traub y Zephyranthes lindleyana Herb.) (Amaryllidaceae). Acta Agricola y Pecuaria 2 (2): 34-42.

Peakall, R., Smouse, P.E. 2012. GenAIEx 6.5: genetic analysis in Excel. Population genetic software for teaching and research-an update. Bioinformatics 28: 2537-2539.
Piperno, D.R. 2011. The origins of plant cultivation and domestication in the New World tropics patterns, process, and new developments. Curr Anthropol 52(4): S453-S470.

Porras-Hurtado, L., Ruiz, Y., Santos, C., Phillips, C., Carrasedo, A., Lareu, M.V. 2013. An overview of STRUCTURE: applications, parameter settings, and supporting software. Frontiers in Genetics 4(98): 1-13.

Pritchard, J.K., Stephens, M., Donnelly, P. 2000. Inference of population structure using multilocus genotype data. Genetics 155: 945-959.

Reif, J.C., Melchinger, A.E., Firsch, M. 2004. Genetical and mathematical properties of similarity and dissimilarity coefficients applied in plant breeding and seed bank management. Crop Sci 45: 17-7.

Rohlf, F.J. 2009. NTSYSpc: Numeral Taxonomy System. Ver. 2.21. Exeter Software. Stauket, New York.

Roldán-Ruiz, I., Dendauw, J., Van, B.E., Depicker, A., De Loose, M. 2000. AFLP markers reveal high polymorphic rates in ryegrasses (Lolium spp.). Molecular Breeding 6:125-134.

Sambrook, J., Russell, D.W. 2001. Molecular cloning: A laboratory manual. (Vol. 1). 3rd Ed. New York: Cold Spring Harbor, pp 1.1-7.94.

Sanguinetti, C.J., Neto, E.D., Simpson, A.J. 1994. Rapid silver staining and recovery of PCR products separated on polyacrylamide gels. Biotechniques 17: 914-921.

Sarwat, M., Das, S., Srivastava, P.S. 2008. Analysis of genetic diversity AFLP, SAMPL, ISSR and RAPD markers in Tribulus terrestris, a medicinal herb. Plant Cell Reports 27: 519-528.

Seyidoglu, S., Zencirkiran, M., Ayasligil, Y. 2009. Position and application areas of geophytes within landscape. African Journal of Agricultural Research 4(12): 1352-1357.

Takrouni, M.M., Boussaid, M. 2010. Genetic diversity and population structure in Tunisian strawberry tree (Arbutus unedo L.). Sci Hortic 126: 330-337.

Tapia-Campos, E., Rodríguez-Domínguez, JM., Revuelta-Arreola, M.M., Van-Tuyl, J., Barba-González, R. 2012. Mexican Geophytes II. The Genera Hymenocallis, Sprekelia and Zephyranthes. Floriculture and Ornamental Biotech 6(1): 129-138.

University of British Columbia. 2015. Ubc Issr Primer Set Cánada https://es.scribd.com/doc/155984113/Ubc-Issr-Primer-Set. Accessed: 12 January 2016.

University State the Ohio. 2000. ISSR Protocols. https://excelsior. asc.ohio-state.edu/ awolfe/ISSR/protocols.ISSR.html. Accessed: 12 January 2016.

Valadez-Moctezuma, E., Samahar, S., Luna-Paz, A. 2015. Genetic diversity of Opuntia spp. varieties assessed by classical marker tools (RAPD and ISSR). Plant Syst Evol 301: 737-747.

Valdés de la Cruz, M., Hernández Yuniet, A., Vázquez Lobo, D., Piñeiro, L., González-Pérez. 2010. Diversidad genética de especies silvestres del genero Nicotiana II: Caracterización molecular mediante marcadores RAPD. Protección Vegetal 25: 166-173.

Vargas-Ponce, O., Pérez-Álvarez, L.F., Zamora-Tavares, P., Rodríguez, A. 2011. Assessing genetic diversity in Mexican Husk tomato species. Plant Mol Biol Rep 29: 733-738.

Velasco-Ramírez, A.P., Torres-Morán, M.I., Molina-Moret, S., Sánchez-González, J.D.J., Santacruz-Ruvalcaba, F. 2014. Efficiency of RAPD, ISSR, AFLP and ISTR markers for the detection of polymorphisms and genetic relationships in camote de cerro (Dioscorea spp.). Electron J Biotechnol 17: 65-71.

Wu, Z.G., Li, X.X., Lin, X.C., Jiang, W., Tao, Z.M., Mantri, N., Fan, C.Y., Bao, Q.X. 2014. Genetic diversity analysis of yams (Dioscorea spp.) cultivated in China using ISSR and SRAP markers. Genet Resour Crop Evol 61: 639-650. 